\title{
Global prospects of unconventional oil in the turbulent market: a long term outlook to 2040
}

\author{
Nikita O. Kapustin ${ }^{1, *}$, and Dmitry A. Grushevenko ${ }^{1,2}$ \\ 1 The Department of Research of Energy Complex of Russia and the World, The Energy Research Institute \\ of the Russian Academy of Sciences, Nagornaya st., 31, k.2, 117186 Moscow, Russia \\ 2 Center for Energy Markets Studies, The Energy Institute of the Higher School of Economics, Moscow, Russia
}

Received: 13 June 2018 / Accepted: 14 September 2018

\begin{abstract}
Unconventional oils have taken the global oil industry by storm and have secured an $8 \%$ share in the global liquid fuels production in under 20 years. And it is without a doubt that these resources will continue to play an important role in the future. Cost analysis of unconventional oil types has shown that Light Tight Oil (LTO) or shale oil still holds potential for technological and economical improvement, however, the revolutionary stage in development has probably already been passed in the US. For the rest of the world, the issue of kick starting LTO production lies as much in the fields of adapting the existing technologies, as overcoming economic, legislative and environmental barriers. The same cannot be said for heavy oil and bitumen production, as open pit mining is demonstrating cost escalation and resource base depletion, while in situ production approach has reached the limit of technological progress and production costs are mostly determined by external factors. Oil price fluctuation and the emergence of more economically viable unconventional oil sources have shifted attention away from kerogen oil and substantially halted production technologies development. The forecast of unconventional oil was conducted along two scenarios: Baseline (a business-as-usual scenario) and Technological (scenario of forced technology development and transfer). The share of unconventional oil in global crude production will increase to $17-21 \%$, depending on scenario. The main difference between scenarios is the rate of kerogen production, which benefits from the favorable conditions of the Technological scenario. Large-scale LTO production will remain a local North American phenomenon in both scenarios. More important than geological or technological factors is the unique business environment, characteristic for the USA, which would be impossible to replicate in any other country. Expansion of unconventional oil production as stimulated competition on the liquid fuels market. Conventional oil producers have mostly adapted to the new environment and will continue to dominate in the forecast period. The greatest pressure is put on the more costly alternative supply sources: biofuels, coal-toliquid and gas-to-liquid; which have the least promising prospects in the current market.
\end{abstract}

\section{Introduction}

Probably the most important breakthrough for the global oil industry in the last decades was the rapid development of new sources of liquid hydrocarbons, collectively referred to as "unconventional oil". Combination of favorable market conditions, new technologies and know-hows and expertise of petroleum engineers has enabled commercial development of resources that for many decades were thought to be unobtainable. By 2018 unconventional oils have mostly proven their competitiveness and claimed their market share. However, there are still many uncertainties about the future development of these resources. For the

\footnotetext{
* Corresponding author: nikita.kapustin@mail.ru
}

sake of this research three most prominent types of unconventional oil there will be analyzed:

- Light Tight Oil (LTO) - light oils, trapped in ultralow permeability reservoirs.

- Heavy oil and natural bitumen - dense, viscous hydrocarbon mixtures, product of conventional oil degradation.

- Kerogen oil (oil shale) - source rock laced with solid organic matter.

The most proverbial of unconventional oil types is undoubtly the LTO, commonly misnamed "shale oil". ${ }^{1}$

\footnotetext{
${ }^{1}$ Shale oil - oil trapped in shale formations is a subtype of tight oil.
} 


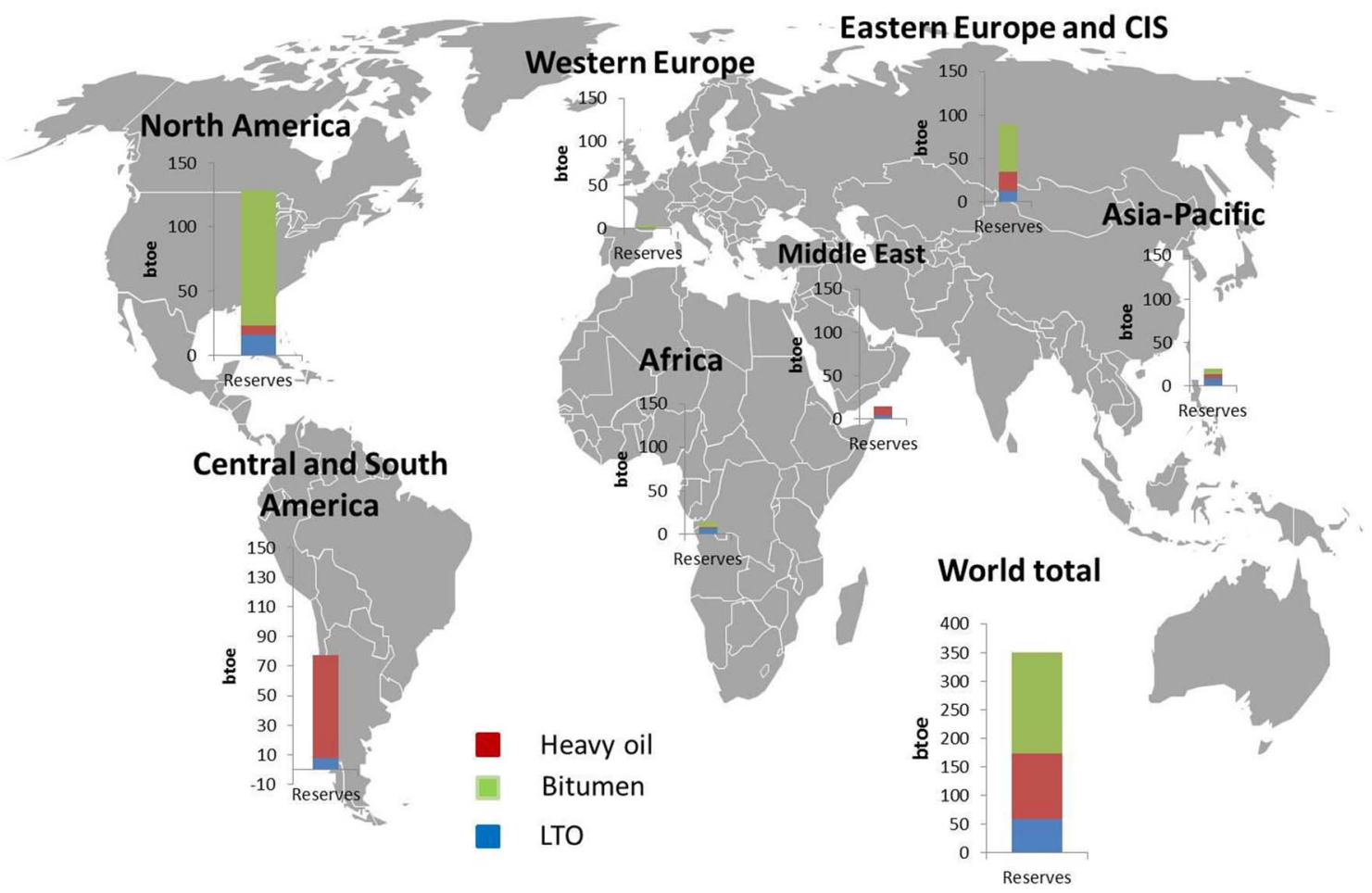

Fig. 1. Geography of unconventional oil technically recoverable reserves (Source: IEA, 2017; Authors' research).

The development of these previously untapped resources has led to a renaissance of USA oil production and caused a revolution in global oil market (Grushevenko and Grushevenko, 2012; Salameh, 2013; Kenneth, 2016), shifting the balance of power and becoming one of major reasons for hydrocarbon prices plunge in 2014-2015. Nowadays, in 2018, over half a decade since the start of shale boom, the main questions persist does US resource base and the evolution of costs and technologies allow for further LTO production expansion or the decline of "shale revolution" is imminent; and whether it is possible to replicate LTO boom outside North America, given the geological, economical and environmental constraints.

This uncertainty is also common for heavy oil and bitumen production (for classification see Proceedings of the Twelfth World Petroleum Congress, 1987). The openpit mining in Alberta (also known as ex situ production techniques), usually associated with this type of unconventional oil has natural resource base limitations, as reserves available for mining comprise only $20 \%$ of total recoverable heavy oil resources (Oil Sands Magazine, 2018a). Thus a range of borehole technologies, collectively referred to as in situ are becoming predominant. Yet, the possibility of large-scale adoption of these technologies outside of Canada, in such countries as Russia, China and Venezuela remains ambiguous and will heavily depend on cost dynamics.

Kerogen oil, also known as oil shale (not to be confused with shale oil), a hydrocarbon source, which was widely considered highly prospective just a few years ago, in
2012 (Makarov, 2012), has now almost completely fallen out of public attention.

In this research we will provide analysis of recent trends in unconventional oil development and costs dynamics. This analysis will become the foundation for scenario-based long-term outlook on unconventional oil production. The outlook will be calculated using state-of-the-art modelling tools for world global oil market forecasting, developed by the authors.

\section{Current state of unconventional oil: global resource base and production}

According to the latest available estimates (USGS, 2003; EIA, 2015; IEA, 2017), global technically recoverable reserves of LTO, heavy oil and bitumen oil measure up to about 350 billion toe, comparable to the contemporary conventional oil reserves. Over $60 \%$ of these resources are concentrated in North and South Americas and considerable resources are found in Eurasian (Eastern Europe and CIS) region while the rest are distributed across other regions of the world relatively evenly (Fig. 1).

At the same time, cumulative production of unconventional oil amounted to roughly 380 million tons, only $9 \%$ of global liquid hydrocarbon output (BP, 2017). Global production is also distributed unevenly, with North America providing 330 million tons of crude, and South America coming second with 60 million tons. 
Table 1. Oil shale development projects in the World (Source: Authors' research)

\begin{tabular}{lll}
\hline Country & \multicolumn{1}{c}{ Projects } & \multicolumn{1}{c}{ Plans } \\
\hline Jordan & El Lajjun & Synthetic oil production was planned \\
& Attarat Um & at 7.5 million tons by 2015. Three \\
& Ghudran & approaches to oil shale development \\
& & were announced: synthetic oil \\
& production through in situ (Shell's ICP \\
& technology) and surface retorting as \\
& well as direct oil shale burning for \\
& power generation.
\end{tabular}

Israel Shfela

Morocco Tarfaya

Australia McFarlane

Latrobe

Julia Creek

Stuart

Rundle

China Fushun

Brazil Irati formation

According to China's National Energy Administration, kerogen oil production can measure up to 10 million tons.

The initial oil was planned to be produced by the end of 2012-beginning of 2013, the planned production volume amounted to 13.5 million tons.
Current state and prospects

Most of the synthetic oil production projects have been postponed beyond 2020 due to oil prices drop and environmental concerns. The first oil shale burning $500 \mathrm{MW} \$ 2.5$ billion power plant project is under development since 2008 by Jordan government in cooperation with Estonian and Chinese parties. Operations are planned to start in 2020.

Projects development has been postponed indefinitely due to legal proceedings between parties. Prospects of oil shale development have been subject of controversy and ecology concerned protests.

In 2016, San Leon Energy suspended financing of the project, until the recovery of oil prices. In the same year, Global Oil Shale suspended the project due to a shift in the company's strategy towards cement production.

In 2008 a 20-year ban was imposed on shale development. In 2011 restrictions were lifted, but ecological and technological requirements have become much stricter.

In 2015, two technologies of in situ oil production using hydraulic fracturing and high-temperature formation treatment were studied and successfully tested, which will be used for the development of deep-seated and more massive deposits. Further modernization and testing of these technologies in the framework of integrated development of shale oil and gas and oil shale production corresponds to the 13th five-year plan of economic and social development until 2020.

$\begin{array}{ll}\text { Estonia } & \begin{array}{l}\text { Graptolitic } \\ \text { Kukersite }\end{array}\end{array}$

Petrobras has been developing oil shale formations since 90's, using the ex situ retorting technology Petrosix. However, currently offshore pre-salt fields hold higher priority for the company, due to kerogen projects' higher costs, geological, technological and ecological challenges.

Kukersite

Due to limited resource base and strict EU ecological legislation, the country's own production is not developing. At the same time, Estonian companies are active at exporting technologies, oilfield services and expertise to China, Jordan and US.

The unquestionable leader in unconventional oil development is the USA. Production of LTO in 2017 amounted to 230 million tons in 2017, about half of country's total crude oil output (EIA, 2018). In addition to vast resources and cutting-edge technologies, extensive infrastructure, technological base and acumen, human resources, proximity of production sites to consumers, availability of loans and fairly liberal legislation for oil fields 
development all played major parts in American "shale revolution".

The success story of USA shale oil spawned interest for these resources in other regions. Argentina is widely considered as the most promising country for a new LTO boom. Technically recoverable reserves of LTO in Argentina are estimated to be over 3.5 billion tons, with over half concentrated in the giant Vaca Muerta formation, containing vast resources of both shale oil and shale gas. Yet, current annual tight oil output is only 2.5 million tons (Qarnain, 2016). Among the main factors, holding back Argentinian shale are lacking infrastructure in the production regions, the need to import technology and equipment, as well as ecological and labor legislation way more strict than that in the US. The combination of these barriers raise Argentina's average LTO production cost by at least $50 \%$ compared to the US (over $\$ 60$ per barrel) (Solbrække and Triana, 2016).

As the world's largest oil importer, China has a strong interest in expanding its own production, and much attention has been paid to exploring the potential of unconventional oil fields at the state level. EIA estimates China's potential technically recoverable reserves of LTO at 4 billion tons. Yet, actual discoveries are modest at best. One of the largest recently discovered tight oil fields boast 100 million tons of geological reserves. Practice shows that the geology of the shale plays in China differs significantly from the fields of the USA (productive tribes of the USA consist of brittle shale of marine origin, while China is dominated by denser lake shale), which makes the direct transfer of production technologies and know-hows from America unreasonable. Amid low oil prices, LTO production in China showed a downward trend and its future prospects are dim (Collins, 2015).

Russian Federation is also considered to possess a vast untapped LTO potential. EIA evaluates Russian tight oil resources at 10 billion tons. The most prominent is the Bazhenov shale. The R\&D works to develop its enormous resources has been going for decades now, yet in 2016 production amounted to just 0.5 million tons (Katona, 2017).

Significant reserves of LTO are also expected in Libya, UAE, Chad, Nigeria, Pakistan. Nevertheless, the study of these resources is at an early stage, which makes it impossible to assess their commercial potential and prospects for further development.

At the moment, the United States possesses unique environment favorable for light tight oil development. In other countries and regions exploration and development of tight oil resources has faced overwhelming technological and legislative barriers, thus unconventional production booms akin to North American are not to be expected in the short term. Argentina and Russia came closest to the commercial development of new resources, and it is likely that these countries will be the pioneers of LTO production outside North America given that governments implement appropriate incentive policies.

With one of the world's largest reserves of heavy oil (over 20 billion tons (Natural Resources Canada, 2017)) and enjoying most of the same advantages as the United States (proximity to markets, infrastructural and technological

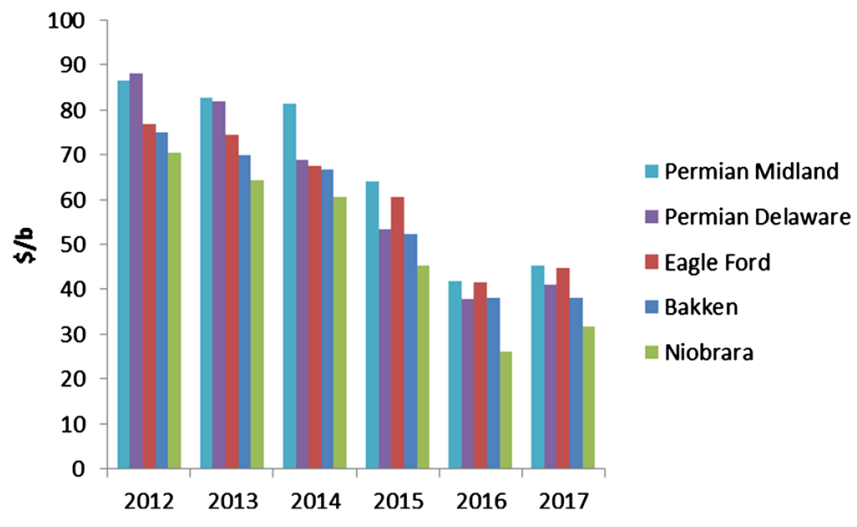

Fig. 2. Dynamics of wellhead break-even prices on key shale formations in USA (Source: Rystad Energy, 2016; OPEC, 2017).

base, liberal legislation), Canada is the undisputed leader in production and the introduction of new technologies for the development of heavy oil and natural bitumen fields. Production of petroleum bitumen and heavy oil in Canada exceeded 100 million tons in 2016. The production of LTO in Canada is also significant, reaching up to $0.425 \mathrm{Mb} / \mathrm{d}$ at the peak in 2014, however limited resource base and unfavorable price environment have caused it to falter and decline to $0.345 \mathrm{Mb} / \mathrm{d}$ in 2016 (National Energy Board, 2017).

Venezuela is often cited as Canada's major future competitor in heavy oil production. Currently, this South American country is officially the world leader in reserves with 47 billion tons (OPEC, 2018). More than $2 / 3$ of these reserves accounted for heavy oil, concentrated mainly in the Orinoco belt (RIGZONE, 2018). Compared to Canadian tar sands, Venezuela's heavy oil deposits are characterized by significantly better quality and comparative simplicity of development (Dusseault, 2001). In practice, the peculiarities of the deposits allow Venezuela to develop its reserves without extensive use of specialized extraction technologies, using only multilateral horizontal wells. Thus, it provides about 50 million tons of annual production, or half of the country's total oil output. Such a method of production, although relatively low in capital intensiveness, is not capable of providing an oil recovery rate above $10 \%$. As the introduction of more efficient technologies is hampered by political instability and inefficient management of the oil and gas industry in the country (Rapier, 2017), a significant increase in the production of heavy oil is not to be expected in short and medium term, despite the significant resource base of Venezuela.

Reserves of heavy oil and natural bitumen in Russia are quite extensive and well-studied; the most promising being the Volga-Ural oil and gas basin (Danilova, 2008). According to USGS, the reserves of heavy oils and natural bitumen are about 6-7 billion tons. However, even despite the rather active policy of the Russian government to support the production of unconventional oils, heavy oil production is still at very low levels, about 500 thousand tons per year, less than $0.1 \%$ of the total production in the country. In the context of declining oil prices, the 
Table 2. Key areas of LTO production economics enchancement, 2012-2017 (Source: Authors' research based on EIA, 2016b; DOE, 2015)

\begin{tabular}{llll}
\hline & & \multicolumn{2}{c}{ Economic efficiency enhancement areas } \\
\cline { 3 - 4 } & & \multicolumn{1}{c}{$\begin{array}{c}\text { Cost } \\
\text { reduction }\end{array}$} & \multicolumn{1}{c}{$\begin{array}{c}\text { Average well } \\
\text { productivity increase }\end{array}$} \\
\hline $\begin{array}{l}\text { Economic efficiency } \\
\text { enhancement areas }\end{array}$ & Drilling & $\begin{array}{l}\text { Rig skidding } \\
\text { Wellhead operations improvement }\end{array}$ & $\begin{array}{l}\text { Longer laterals } \\
\text { Improved geosteering }\end{array}$ \\
& & Multiple use of drilling rigs & $\begin{array}{l}\text { Well grid optimisation } \\
\text { Exploitation }\end{array}$ \\
& & Fracking speed increase & Superfracks \\
& Proppant cost reduction & Optimisation of stages and positioning \\
& & of fracturing \\
& & Hybrid fracking liquids \\
\hline
\end{tabular}

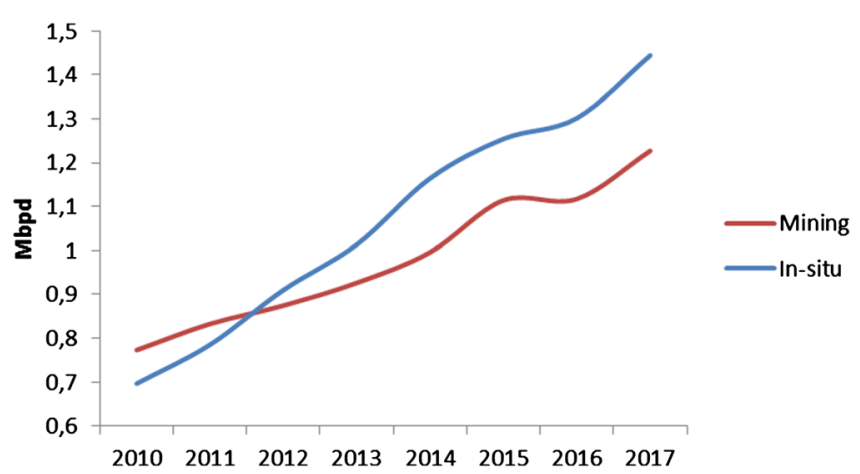

Fig. 3. Production of super-heavy oil and bitumen in Canada by various methods (Source: CAPP, 2018; Oil Sands Magazine, 2018b, 2018c).

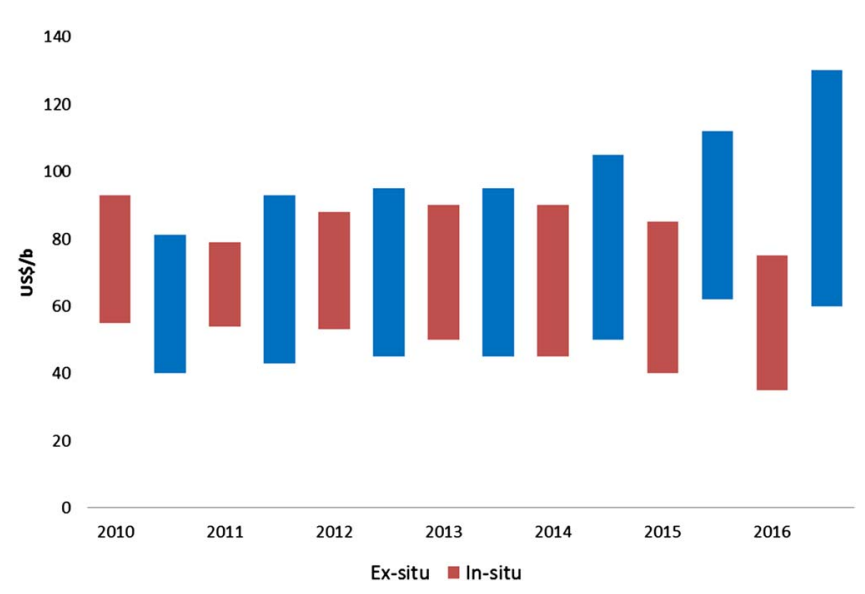

Fig. 4. Break-even prices range for oil sands and heavy oil projects in Canada (Source: Millington, 2017; Lettis, 2016),

current traditional resources are more attractive to oil companies, and their reserves so far allow maintaining record production levels.

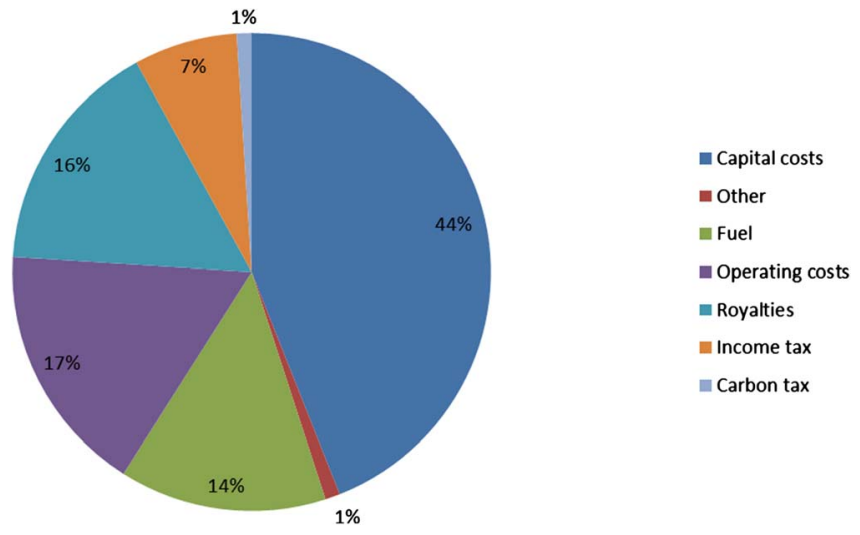

Fig. 5. SAGD cost decomposition (Source: Millington, 2017).

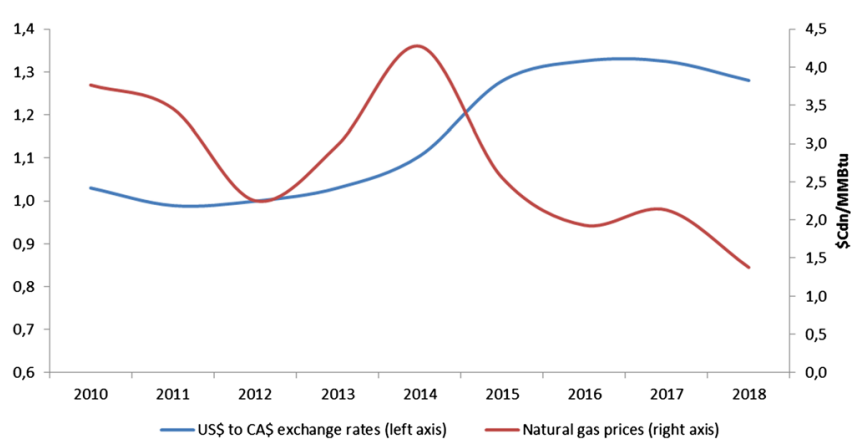

Fig. 6. US $\$$ to $\mathrm{CA} \$$ exchange rates and natural gas prices in Canada (Source: X-rates.com, 2018; Natural Resources Canada, 2018).

Resources of oil shale plays are widespread all over the world. More than 600 places of occurrence are known in 33 countries on all continents, and their global reserves are estimated as more than 1 trillion tons (WECouncil, 2016, p. 16). According to IEA World Energy Outlook 2017 global technically recoverable reserves of kerogen oil 


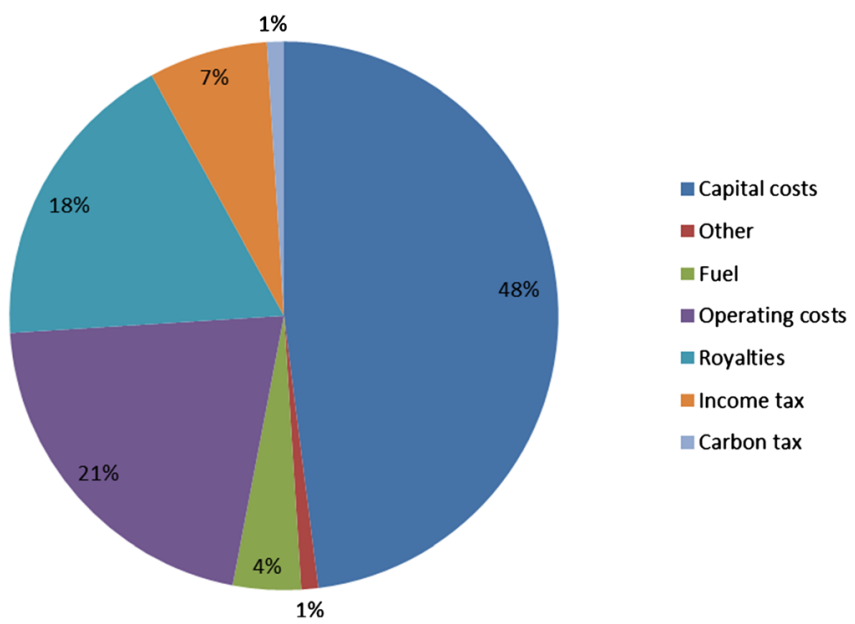

Fig. 7. Mining cost decomposition (Source: Millington, 2017).

amounted to 170 billion tons. However, only a handful of projects exist in several countries across the globe.

Since oil shale development projects carry high economic risks (expensive technologies and large-scale investments in their development) and environmental implications (impact on the soil and huge water consumption), no pilot project has yet entered the phase of extracting industrial volumes of oil shale (Tab. 1). The most likely outcome for such projects is their suspension "until better times" or outright abandonment. For instance, Chevron has announced its rejection of the license to develop the Piceance oil shale field in Colorado and redirection of financial and human resources to other, more cost-effective projects in the United States and the world (Hooper, 2012). Royal Dutch Shell has closed the project of oil shale development in Colorado on the site Rio Blanco County, deciding to focus on more promising sites in Jordan and Canada (Webb, 2013). The company has later also sold its shale assets in Canada as part of a restructuring of its investment portfolio in line with its long-term strategy (Shell Canada, 2017).

Thus, it is too early to anticipate a breakthrough in the development of oil shale, only the gradual development of pilot projects is expected with the start of commercial production not earlier than the 2030s.

\section{Unconventional oil cost analysis}

\subsection{Economy of LTO}

Traditionally, the key indicator for comparative analysis of both individual upstream oil projects and entire industries, such as unconventional oil is the break-even price. Breakeven price is the price of oil at which the Net Presented Value (NPV) of the given oil production project is positive and the Internal Return Rate (IRR) is at an acceptable level for the operator, usually in the range from $10 \%$ to $20 \%$ (Grushevenko and Grushevenko, 2012; Makarov, 2012; Makarov and Grigoriev, 2012).

During the "Shale Oil Boom" in the US in the 20122016 period break-even prices of LTO have dropped by more than half on the key plays from $70-85$ US $\$ /$ bbl to 30-41 US\$/bbl, however in 2017 a slight rise in costs occurred. This could be interpreted as a turning point, but more probably is a development stump (Fig. 2).

These dynamics, however, were not driven by any new technological breakthrough, but rather the evolution of the existing directional drilling and multistage hydraulic fracturing (commonly known as fracking) technologies that made shale development possible in the first place. This evolution is taking place over two main areas: increasing the economic efficiency of drilling and operation of wells by reducing the cost of work and component materials; as well as increasing the technological parameters of drilling and operations (Tab. 2).

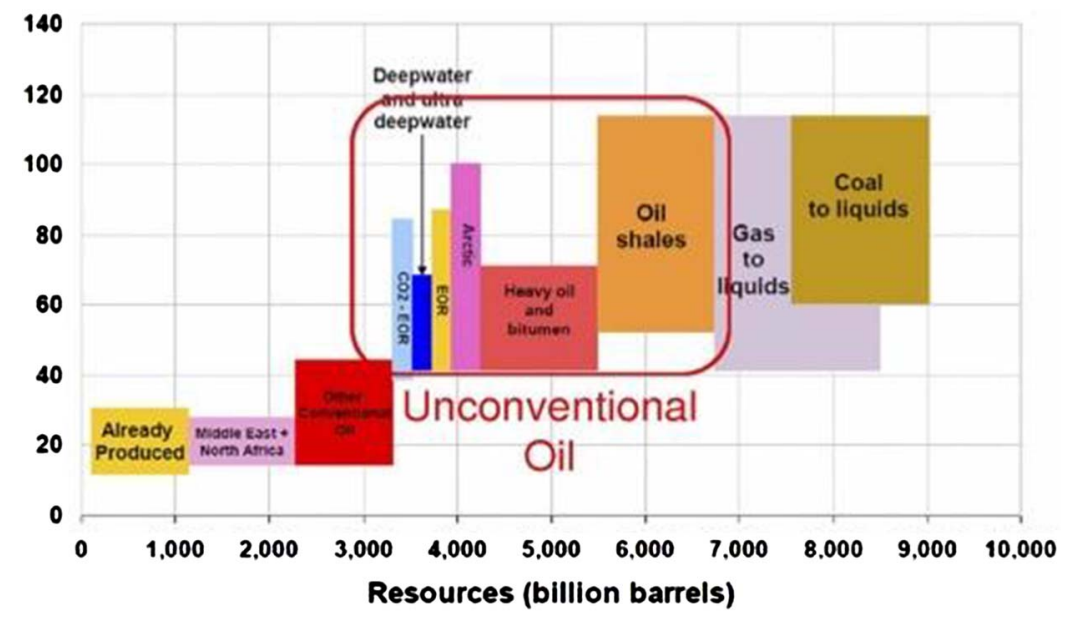

Fig. 8. The position of kerogen oil on the liquid fuels supply curve (Source: IEA, 2015). 


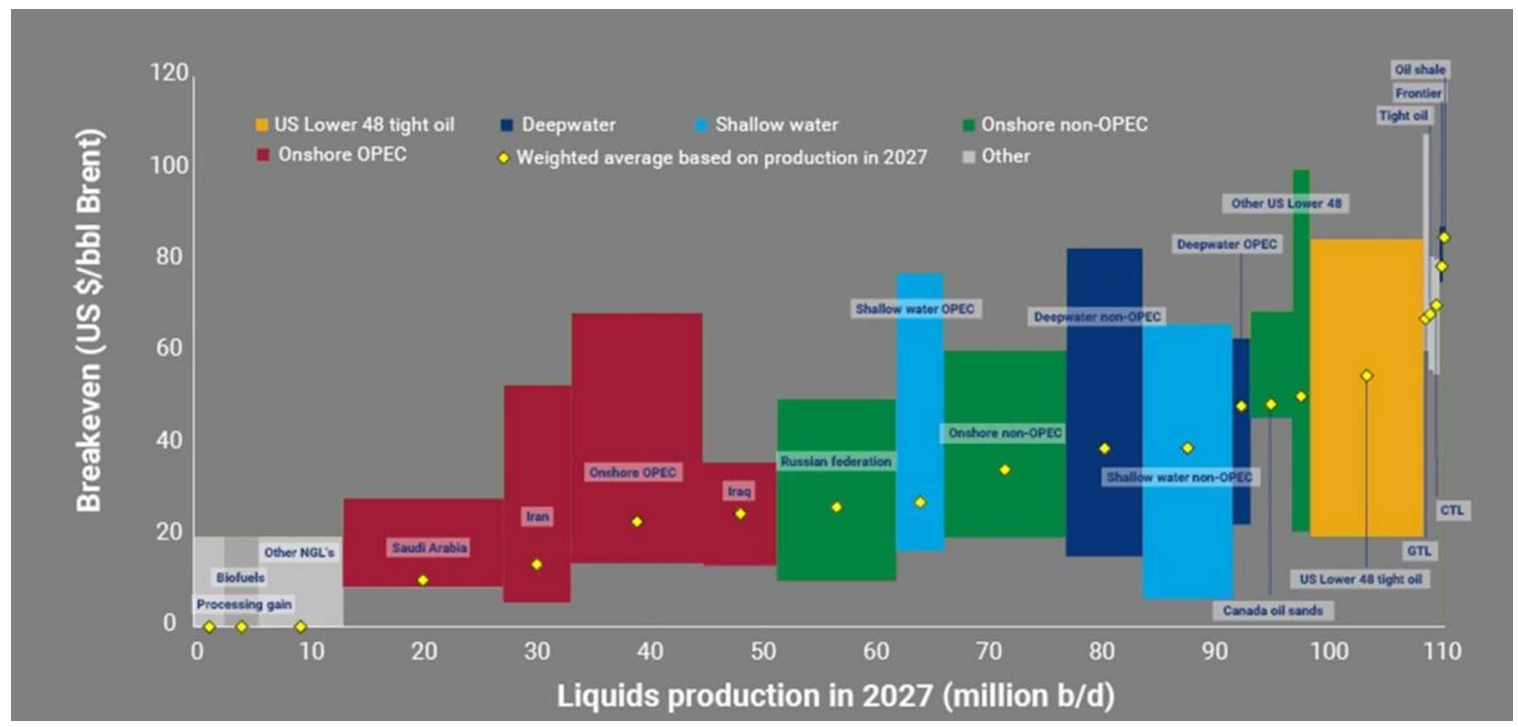

Fig. 9. Global cost curve in 2027 (Source: Paton, 2018)

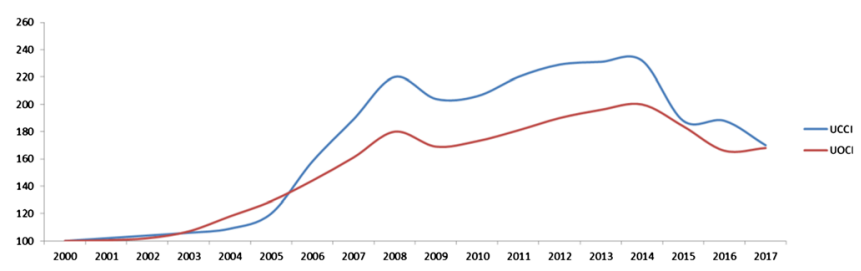

Fig. 10. Operating and capital cost indexes of conventional oil projects (Index, $2000=100$ ) (Source: IHS Markit, 2018).

\subsection{Economy of heavy oil and bitumen}

Since 2011 in situ techniques have been providing more oil than mining and the spread is growing (Fig. 3).

This trend is reinforced by diverging break-even price dynamics. The open-pit mining costs have been on the rise since 2014, while in situ approach has been stable, even demonstrating a slight decline (Fig. 4).

Several factors have put a downward pressure on in situ production cost. The costs decomposition for Steam Assisted Gravity Drainage (SAGD), the most prominent of in situ techniques, shows a relatively high share of fuel expenses (14\%) and even higher fraction of operating costs (17\%) (Fig. 5).

Exceptionally low natural gas prices, affected by US shale gas boom, coupled with the devaluation of Canadian dollar (Fig. 6) helped cut the US\$ costs of the aforementioned expenses. The latter is also important for construction costs, as SAGD mostly employs domestic technology.

The same cannot be said for ex situ production. Despite comparable costs structure (except for the energy component) (Fig. 7) open-pit mining relies heavily on mostly imported machinery, made only more expensive to acquire and maintain by weakening currency.

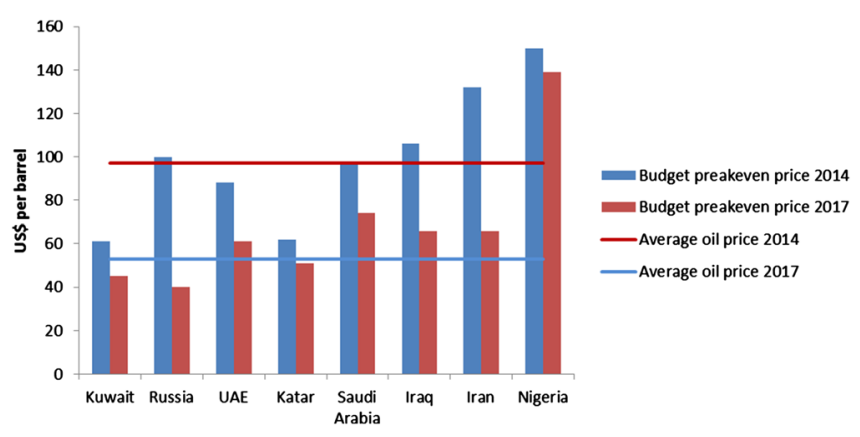

Fig. 11. Oil break-even prices for the budgets of leading oil producers (Source: Authors' research, based on Slav, 2017 and Carpenter, 2017).

Thus, it can be assumed, that both in situ and ex situ technologies have mostly passed the limits of cost-reduction due to technology improvement and further cost dynamics will be determined by external factors.

\subsection{Economy of kerogen oil}

The techniques associated with kerogen oil production are not dissimilar to those for heavy oil, yet according to most researchers, kerogen is undoubtedly the most costly of all hydrocarbon sources currently available to mankind with break-even prices of at least 75-105 US $\$ /$ bbl even with the devaluation benefits and low natural gas prices. Thus kerogen is firmly established on the right side of the supply curve (Fig. 8).

According to WoodMackenzie analysis (Paton, 2018), the structure of the supply curve will mostly remain the same in the coming decade (Fig. 9) indicating no expected technological breakthrough. 


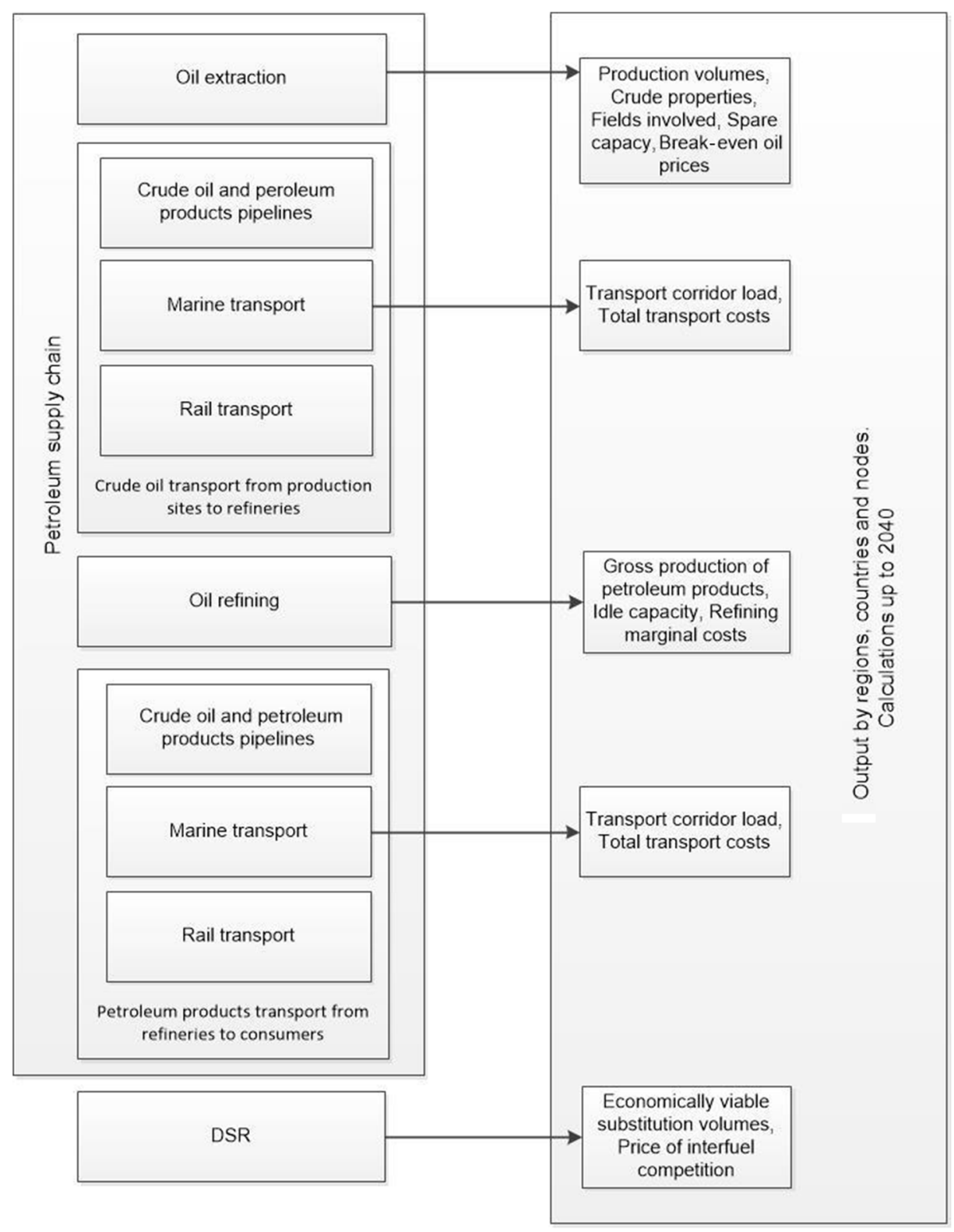

Fig. 12. Supply chain of crude oil and petroleum products from the field to the consumer (Source: Grushevenko and Kapustin, 2017).

\subsection{Economy of conventional oil}

Composing an outlook of unconventional oil production would be impossible without taking into account the economics of its main competition - that is the conventional oil. Despite a sharp price drop in 2014-2015, most of the key oil producers managed to maintain or even increase oil production. Crude supply from Brazil grew by 24 million tons per annum. Iran, Iraq and Saudi Arabia increased yearly production by 35,66 and 36 million tons respectively, while cumulative increment of supply from Middle East exceeded 150 million tons. Even Russia managed to provide additional 30 million tons to the market despite the sanctions burden. This came to be due to a substantial decrease in global average production costs, achieved through a combination of national currencies devaluation (as mostly the case with Russia) and tax cuts (as in the case of Canada, Kazakhstan, Colombia, Iraq; Nakhle, 2016) (Fig. 10).

The adaptation to low oil prices also extended to national budgets. Thus, in just four years (2014-2017) all major oil producers: Kuwait, Russia, Qatar, UAE, Saudi Arabia, Iraq, Iran and Nigeria reported decrease in their budget break-even oil prices (i.e. oil prices necessary to maintain deficit-free budget) (Fig. 11). The only major producer not to adapt was Venezuela (Denning, 2017).

And while conventional oil producers managed to negate the short-term effects of low oil prices, market 
Table 3. Key scenario assumptions (Source: Author's research)

\begin{tabular}{|c|c|c|c|}
\hline Scenario & LTO & Heavy oil and bitumen & Kerogen oil \\
\hline Baseline & $\begin{array}{l}\text { Up until 2020, a slow } \\
\text { reduction in costs occurs. } \\
\text { The resource base is not } \\
\text { considerably expanded } \\
\text { by new discoveries or } \\
\text { breakthrough } \\
\text { technologies. Large-scale } \\
\text { production does not go } \\
\text { beyond North America. } \\
\text { Some projects are } \\
\text { developed in Russia, } \\
\text { Argentina, China. }\end{array}$ & $\begin{array}{l}\text { A gradual escalation of } \\
\text { costs takes place over the } \\
\text { forecast period. The } \\
\text { resource base is not } \\
\text { expanded significantly. } \\
\text { Large scale production is } \\
\text { carried out in North } \\
\text { America; individual } \\
\text { projects are launched in } \\
\text { Russia, Venezuela and } \\
\text { several other countries. }\end{array}$ & $\begin{array}{l}\text { Kerogen resources do not } \\
\text { pass into commercially } \\
\text { recoverable category in the } \\
\text { forecast period. Production } \\
\text { is carried out in the } \\
\text { framework of pilot projects }\end{array}$ \\
\hline Technological & $\begin{array}{l}\text { Up until } 2020 \text { a slow cost } \\
\text { reduction occurs. } \\
\text { Resource base is } \\
\text { expanded due to new } \\
\text { discoveries, including } \\
\text { large-scale production in } \\
\text { Russia, China and } \\
\text { Argentina. }\end{array}$ & $\begin{array}{l}\text { Slow process of efficiency } \\
\text { improvement takes place } \\
\text { over the forecast period. } \\
\text { In situ technology gradually } \\
\text { becomes the predominant } \\
\text { approach. Average } \\
\text { production costs decrease. } \\
\text { Russia, Venezuela, China } \\
\text { and other countries initiate } \\
\text { commercial production. }\end{array}$ & $\begin{array}{l}\text { Heavy oil and bitumen } \\
\text { production technologies } \\
\text { are adopted for kerogen } \\
\text { production, allowing to } \\
\text { establish full-scale } \\
\text { production at } 45-85 \text { US } \$ \text { / } \\
\text { barrel. Ecological concerns } \\
\text { are overcome through } \\
\text { technological advances. } \\
\text { Projects are launched in } \\
\text { Morocco, Israel, Australia, } \\
\text { China and Mongolia. }\end{array}$ \\
\hline
\end{tabular}

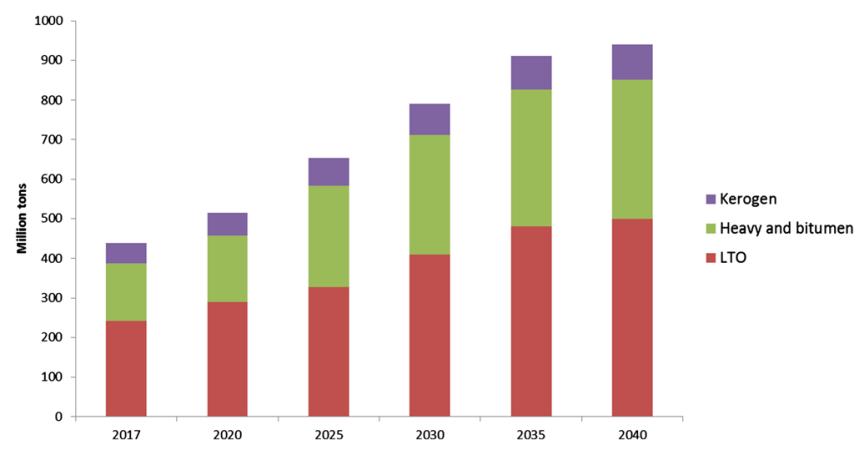

Fig. 13. Unconventional oil production, Baseline scenario. (Source: Author's research).

dynamics led to a sharp drop of investment in oil industry, from 681 billion US\$ in 2014 to 436 billion US\$ in 2016 (IEA, 2018a). In 2017 upstream investment rebounded with a $4 \%$ growth due to sustained oil prices recovery mostly driven by spendings in North America (IEA, 2018b). In the volatile price environment, relatively short shale projects turned out as more attractive for many investors (Stedman and Green, 2017) while capital spending on other oil types, both conventional and unconventional remains discreet. Yet, given the substantial inertia of the industry, the impact of divestment will not become apparent until 2020 's.

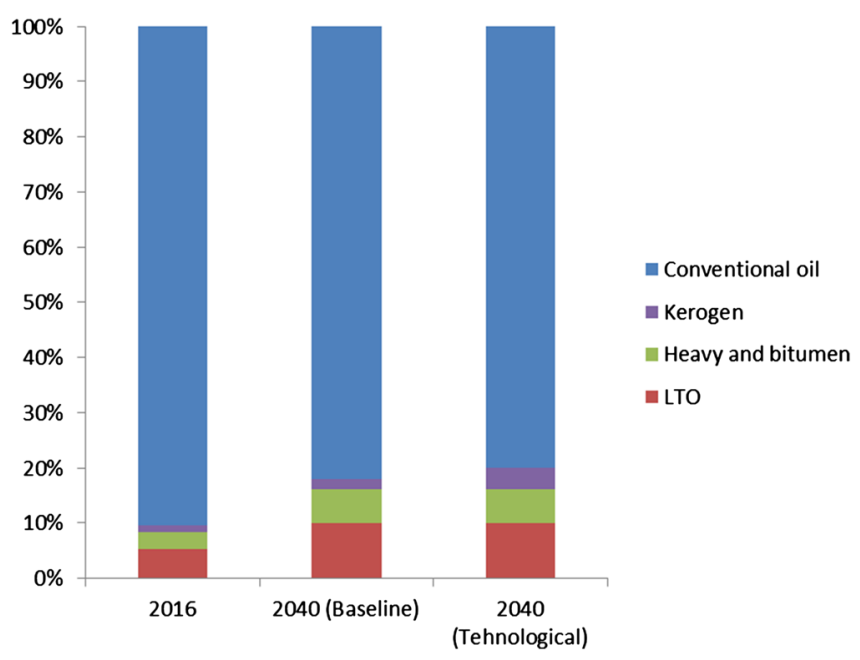

Fig. 14. The structure of oil production by 2040 according to the scenarios (Source: Author's research).

\section{Unconventional oil production outlook}

According to the study, unconventional oil has already made a significant impact on the contemporary oil market. However, despite the fait accompli of the American "shale revolution" and large-scale development of Canada's oil 


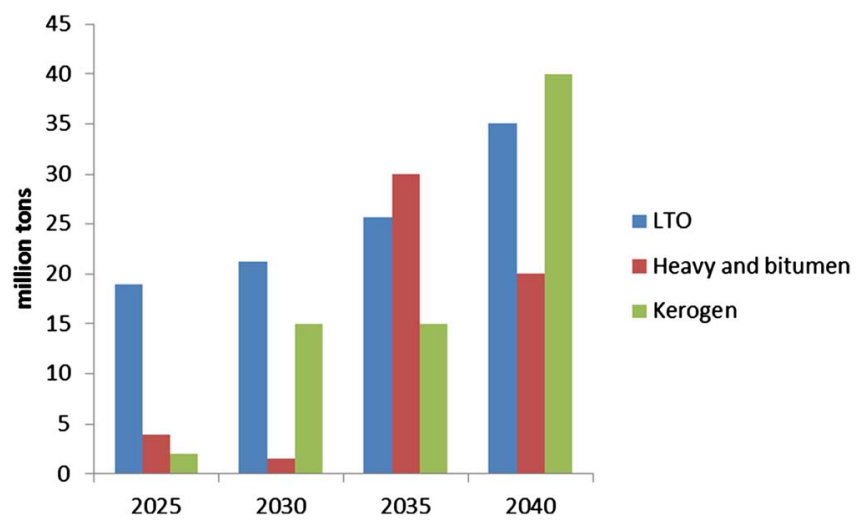

Fig. 15. Increment production in the Technological scenario, compared to Baseline by unconventional oil type (Source: Author's research).

sands, there are still significant uncertainties associated with the future potential for their production. We consider the rate of development of production technologies for low permeability reservoirs and heavy oil as key factor, which will determine the further dynamics of the cost of unconventional oil production, and as a result, its competitiveness in the global market, and therefore, production volumes.

In this section we will provide an outlook on unconventional oil production using state-of-the-art forecasting tool described below.

\subsection{Forecast methodology}

World liquid fuels market model is a static optimization model of full equilibrium. The model uses an extensive database, containing information on crude oil and NGL production capacities, oil refineries capacities, liquids transportation capacities and other characteristics of the petroleum industry as source data. The model covers the entire production chain of the oil market from extraction of crude to the production and marketing of petroleum products and alternative liquid fuels (Fig. 12). Full description of the calculation algorithm is presented in the previous work by the authors (Grushevenko and Kapustin, 2017).

\subsection{Scenario assumptions}

To provide a comprehensive outlook on the global unconventional oil production potential we have formulated two scenarios (Tab. 3):

1. Baseline is a business-as-usual scenario, with technological progress going at a moderate pace; resource base remains constant; kerogen oil production techniques do not develop significantly.

2. Technological scenario sees more rapid evolution of LTO and heavy oil extraction technologies compared to the Baseline scenario; kerogen oil resources are developed through adaptation of in situ heavy oil techniques.
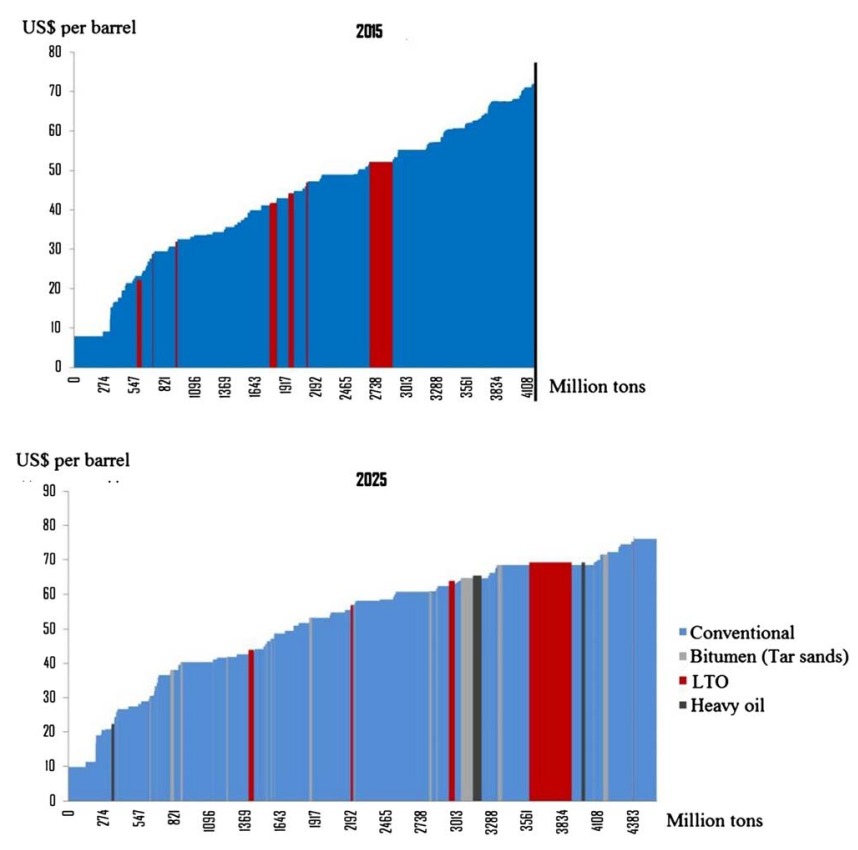

Fig. 16. Oil supply curves in 2016 and 2025 (Source: ERI RAS).

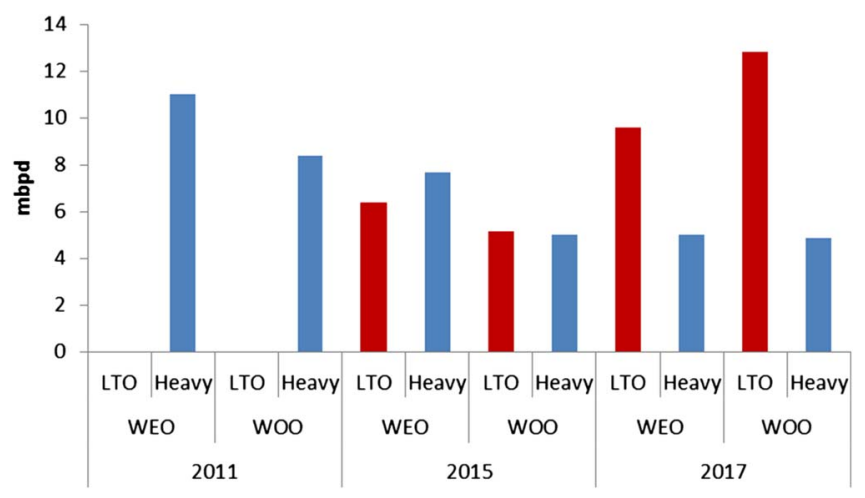

Fig. 17. Unconventional oil production in 2035 forecast dynamics by IEA (WEO) and OPEC (WOO) (Source: Authors' research based on IEA, 2011, 2015, 2017 and OPEC, 2011, 2015, 2017).

\subsection{Results and discussion}

The Baseline scenario assumptions already provide enough grounds for doubling of unconventional oil production over the forecast period, from 440 million tons in 2016 to 854 million tons in 2040 (Fig. 13).

The share of unconventional sources in global production also doubles from $8.5 \%$ in 2016 to $17 \%$ in 2040 (Fig. 14).

Thus, unconventional resources occupy a significant market niche, proving their long term costs competitiveness with conventional oil at the current rate of development and the absence of breakthrough production technologies. 


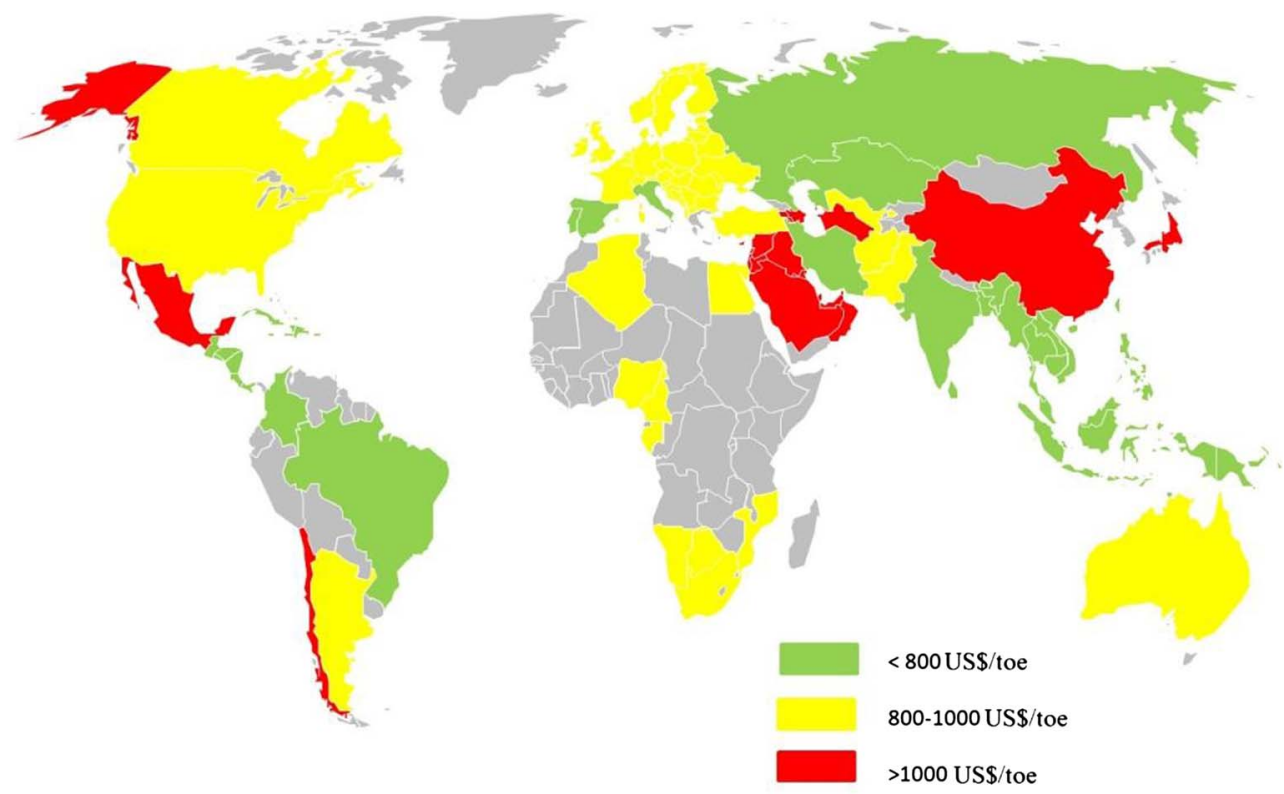

Fig. 18. Gasoline and diesel break-even prices for biofuels across the world's countries (Source: ERI RAS).

The parameters of Technological scenario ensure an additional production growth, with unconventional oil market share increasing to $21 \%$ by 2040 . The main beneficiary in the Technological scenario is the oil shale production. Two major issues of kerogen oil production: high costs and environmental impact have so far hindered its development almost to a complete halt. Technological scenario assumes rapid development and implementation of new, cleaner and cheaper extraction technologies. The main breakthrough will be the full-scale adoption of in situ retorting, which will cut production costs and radically reduce negative impact on biosphere. Introduction of Carbon Capture and Storage (CCS), on the other hand, will help mitigate high carbon dioxide emissions, commonly associated with in situ technologies. Thus the scenario assumptions provide the environment for more rapid kerogen oil development, mainly in China and Australia (Fig. 15).

\section{Conclusion}

Unconventional oil has already made a considerable impact on global oil market and, according to our estimates, will remain a significant source of hydrocarbons in the foreseeable future.

We predict that large-scale LTO production will, most probably, remain a local North American phenomenon in both scenarios. More important than geological or technological factors is the unique business environment, characteristic for the USA, which would be impossible to replicate in any other country. The production techniques for this resource, however still bear potential for development and further growth of North American production is quite likely.
The development of LTO production technologies over the forecast period leads to significant expansion of the supply curve, mainly the middle part (30-60 US\$ per barrel range) (Fig. 16).

Cost analysis of heavy oil and bitumen production, on the other hand, has not demonstrated much room for improvement. Moreover, even under the most favorable conditions of the Technological scenario, heavy and kerogen oil are firmly planted on the right side of the supply curve. As long the other sources remain, the production of these oil types will be limited, despite the enormous resource base.

Introduction of unconventional oil to the market has stirred up competition and complicated the market structure. Our calculations show, that conventional oil, which has demonstrated exceptional adaptability to price fluctuations, will continue to dominate supply of liquid hydrocarbons, while unconventionals will mostly compete among themselves. Thus the LTO, being the most economically viable resource, takes away investment from the less valuable and more costly heavy oil. This is reflected in the dynamics of unconventional oil forecasts, which, over time, seem to increasingly favor LTO (Fig. 17).

At the same time, LTO and heavy oil are, to an extent, complimentary commodities, as both are used for blending to produce medium-grade crude most suitable for refining (Makarov et al., 2016) thus shale oil production serves as a "crutch" for heavy oil, ensuring its production.

The same cannot be said for other, even more expensive alternatives. Prospects of shale discoveries all over the world have rendered coal-to-liquid and gas-to-liquid projects almost obsolete, not even registered in IEA's World Energy Investment 2018 report (IEA, 2018b).

Biofuels are also becoming increasingly less popular. Full production cost of a ton of biofuels amounts to 720 US\$. At 64 US\$ per barrel of crude oil, the price of a 


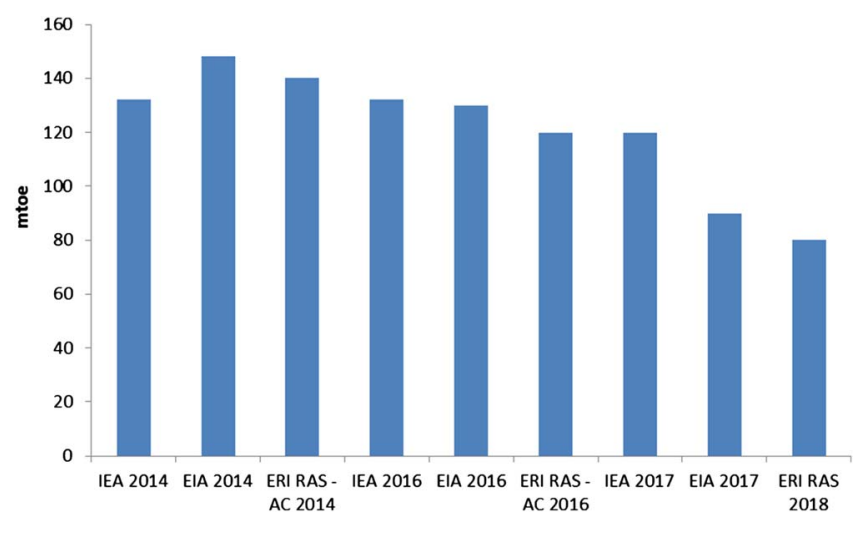

Fig. 19. Biofuels productions in 2025 forecasts (Source: Authors' research, based on Makarov et al., 2014, 2016; IEA, 2014, 2016, 2017; EIA, 2014, 2016a, 2017).

ton of gasoline equals 540 US\$. Thus the break-even oil price for biofuels is estimated at 90-95 US\$ per barrel. The break-even petroleum fuels prices for biofuels across the world are presented in Figure 18.

Moreover, first-gen biofuels have already been long under scrutiny for possible disruptions of biospheres and potential negative effects on land use, agricultural production systems, habitats, biodiversity, land, air and water qualities (UNEP, 2008) and have been losing support. With second-gen still being just a hazy prospect (Center for Biological Diversity, 2016), it is only natural that world's leading energy research agencies that have consistently revised the biofuels production outlooks downwards over the last 4 years (Fig. 19).

\section{Funding}

The author(s) received no financial support for the research, authorship, and/or publication of this article.

\section{References}

BP (2017) Statistical Review of World Energy 2017, London.

CAPP (2018, February) Statistical Handbook for Canada's Upstream Petroleum Industry, Calgary.

Carpenter C. (2017) Kuwait is best off, Nigeria Worst in Fitch's 2017 Oil break-even. Bloomberg. Available at https:// www.bloomberg.com/news/articles/2017-04-06/kuwait-is-bestoff-nigeria-worst-in-fitch-s-2017-oil-break-even (accessed 1 June 2018).

Center for Biological Diversity (2016) United Nations Urged to Withdraw Misleading Biofuels Report. Available at: https:// www.biologicaldiversity.org/news/press_releases/2016/ biofuels-04-07-2016.html (accessed 5 September 2018).

Collins G. (2015) China peak oil: 2015 is the year. The Diplomat, 7 July. Available at http://thediplomat.com/2015/07/chinapeak-oil-2015-is-the-year/ (accessed 1 June 2018).

Danilova E. (2008) Тяжелые нефти России [Heavy oils of Russia]. Chem. J., December, 34-37.
Denning L. (2017) Venezuela's perfect storm for oil may be about to break, Bloomberg. Available at https://www.bloomberg. com/gadfly/articles/2017-07-21/venezuela-oil-storm-may-beabout-to-hit-the-market (accessed 1 June 2018).

DOE (2015) Quadrennial Technology Review. Available at https://www.energy.gov/quadrennial-technology-review2015 (accessed 1 June 2018).

Dusseault M.B. (2001) Comparing Venezuelan and Canadian heavy oil and tar sands, Petroleum Society of Canada, DOI: $10.2118 / 2001-061$.

EIA (2014) International Energy Outlook 2014, Washington.

EIA (2015) World Shale Resource Assessments. Available at https://www.eia.gov/analysis/studies/worldshalegas/ (accessed 1 June 2018).

EIA (2016a) International Energy Outlook 2016, Washington.

EIA (2016b) Trends in US Oil and Natural Gas Upstream Costs, Washington.

EIA (2017) International Energy Outlook 2017, Washington.

EIA (2018) How much shale (tight) oil is produced in the United States? Available at https://www.eia.gov/tools/faqs/faq. php?id $=847 \& \mathrm{t}=6$ (accessed 1 June 2018).

Grushevenko D., Kapustin N. (2017) Methodology for forecasting the global liquid fuels market, Proceedings of 2017 10th International Conference Management of Large-Scale System Development, MLSD $201 \%$.

Grushevenko E., Grushevenko D. (2012) Unconventional oil potential tends to change the World oil market, CSCanada 34 Energy Sci. Technol. 4, 1, 68-74. DOI: 10.3968/j.est. 1923847920120401.178.

Hooper T. (2012) Chevron giving up oil shale research in western Colorado to pursue other projects, The Colorado Independent, 29 December. Available at http://www.coloradoindependent. com/114365/chevron-giving-up-oil-shale-research-in-westerncolorado-to-pursue-other-projects (accessed 1 June 2018).

IEA (2011) World Energy Outlook 2011, Paris.

IEA (2014) World Energy Outlook 2014, Paris.

IEA (2015) World Energy Outlook 2015, Paris.

IEA (2016) World Energy Outlook 2016, Paris.

IEA (2017) World Energy Outlook 2017, Paris.

IEA (2018a) Oil 2018. Analysis and Forecasts to 2023, Paris.

IEA (2018b) World Energy Investment 2018, Paris.

IHS Markit (2018) Costs \& Strategic Sourcing, Available at https://www.ihs.com/info/cera/ihsindexes/ (accessed 1 June 2018).

Katona V. (2017) Can Russia develop its shale reserves? OilPrice.com, 5, September. Available at http://oilprice. com/Energy/Crude-Oil/Can-Russia-Develop-Its-ShaleReserves.html (accessed 1 June 2018).

Kenneth B.M. III (2016) The Shale Revolution and its Implications the World Energy Market, IEEJ J., Special Issue, July.

Lettis, D. (2016) Suncor energy's huge bet on oil sands might be a bad gamble. The Canadian oil sands come with potential benefits, but major risks, too, The Motley Fool, 3 August. Available at https://www.fool.com/investing/2016/08/03/suncor-energyshuge-bet-on-the-oil-sands-might-be.aspx (accessed 1 June 2018).

Makarov A. (2012) Нефть сланцевыbич плеев - новый вызов

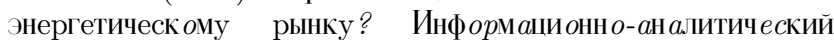
обзор [Oil of shale plays - a new challenge for energy market? Review and analysis], ERI RAS, Moscow, ISBN: 978-5-91438010-3.

Makarov A., Grigoriev L., Mitrova T. (eds) (2014) Global and Russian Energy Outlook to 2040, ERI RAS - ACFR, Moscow. 
Makarov A., Grigoriev L. (eds) (2012) Global and Russian energy outlook until 2035, ERI RAS - REA, Moscow.

Makarov A., Grigoriev L., Mitrova T. (eds) (2016) Global and Russian Energy Outlook, ERI RAS - ACFR, Moscow.

Millington D. (2017) Canadian oil sands supply costs and development projects (2016-2036), Canadian Energy Research Institute, Calgary.

Nakhle C. (2016) How oil prices Impact Fiscal Regimes, Lebanese Center for Policy Studies. Available at https:// www.lcps-lebanon.org/publications/1473842961-policy _ brief_22_web.pdf (accessed 1 June 2018).

National Energy Board (2017) Market Snapshot: Canadian tight oil production decreased after 2014 due to less drilling activity, Canada. Available at https://www.neb-one.gc.ca/nrg/ ntgrtd/mrkt/snpsht/2017/06-03cndntghtlprdctn-eng.html (accessed 5 September 2018).

Natural Resources Canada (2017) Oil Resources. Canada has the third-largest proven oil reserve in the world, most of which is in the oil sands. Available at http://www.nrcan.gc.ca/ energy/oil-sands/18085 (accessed 1 June 2018).

Natural Resources Canada (2018) Natural Gas Facts. Available at https://www.nrcan.gc.ca/energy/facts/natural-gas/20067 (accessed 1 June 2018).

Oil Sands Magazine (2018a) Surface mining techniques used in the oil sands. Available at http://www.oilsandsmagazine.com/ technical/mining/surface-mining (accessed 1 June 2018).

Oil Sands Magazine (2018b) In-situ bitumen extraction. Available at http://www.oilsandsmagazine.com/technical/in-situ (accessed 1 June 2018).

Oil Sands Magazine (2018c) Mining operations. Available at http://www.oilsandsmagazine.com/projects/oilsands-mining (accessed 1 June 2018).

OPEC (2011) 2011 OPEC World Oil Outlook, Vienna.

OPEC (2015) 2015 OPEC World Oil Outlook, Vienna.

OPEC (2017) 2017 OPEC World Oil Outlook, Vienna.

OPEC (2018) Venezuela facts and figures. Available at http:// www.opec.org/opec_web/en/about_us/171.htm (accessed 1 June 2018).

Paton H. (2018) Can conventional oil projects compete with L48 oil? WoodMackenzie. Available at https://www.woodmac.$\mathrm{com} /$ news/opinion/can-conventional-oil-projects-competewith-148-oil/ (accessed 5 September 2018).

Proceedings of the Twelfth World Petroleum Congress (1987) Wiley, New York.

Qarnain F. (2016) Shale drilling set to take off in Argentina, OilPrice.com, 21 July. Available at https://oilprice.com/
Energy/Energy-General/Shale-Drilling-Set-To-Take-Off-InArgentina.html (accessed 1 June 2018).

Rapier R. (2017) How Venezuela ruined its oil industry, Forbes, 17 May. Available at https://www.forbes.com/sites/rrapier/ 2017/05/07/how-venezuela-ruined-its-oil-industry/ \#d691e117399d (accessed 1 June 2018).

RIGZONE (2018) Venezuela's New Focus on Heavy Oil. Available at http://www.rigzone.com/training/heavyoil/ insight.asp?i_id=185 (accessed 1 June 2018).

Rystad Energy (2016) NASWellCub. Available at Subscription Service (accessed 1 June 2018).

Salameh M.G. (2013) Impact of US Shale Oil Revolution on the Global Oil Market, the Price of Oil \& Peak Oil, International Association for Energy Economics. Available at https:// www.iaee.org/en/publications/newsletterdl.aspx?id=202 (accessed 1 June 2018).

Shell Canada (2017) Shell divests oil sands interests in Canada for net consideration of US\$7.25 billion. Available at http:/ www.shell.ca/en_ca/media/news-and-media-releases/newsreleases-2017/shell-divests-oil-sands-interests-in-canada.html (accessed 1 June 2018).

Slav I. (2017) Back to Black: At $\$ 50$ oil, Russia could soon be deficit-free, Oilprice.com. Available at https://oilprice.com/ Energy/Oil-Prices/Back-To-Black-At-50-Oil-Russia-CouldSoon-Be-Deficit-Free.html (accessed 1 June 2018).

Solbrække K., Triana B.V. (2016) Is Vaca Muerta competitive in today's market? OGFJ, 15 November. Available at http:// www.ogfj.com/articles/print/volume-13/issue-11/features/ market-development-in-argentina.html (accessed 1 June 2018).

Stedman A., Green P.K. (2017) Global petroleum survey 2017, Fraser Institute, ISBN 978-0-88975-476-8.

UNEP (2008) Biofuels and agro-biodiversity, Bonn, Germany.

USGS (2003) Heavy oil and natural bitumen - Strategic petroleum resources. Available at https://pubs.usgs.gov/fs/ fs070-03/fs070-03.pdf (accessed 1 June 2018).

Webb D. (2013) Shell shutdown doesn't shake oil shale industry, The Daily Sentinel, 26 September. Available at https:// www.gjsentinel.com/news/western_colorado/shell-shutdown-doesn-t-shake-oil-shale-industry/article_e1e5fc86-e106518d-8e0e-f56996c75e44.html (accessed 1 June 2018).

WECouncil (2016) World Energy Resources 2016, World Energy Council, London. ISBN: 978-0-946121-29-8.

X-rates.com (2018) USD/CAD exchange rates. Available at https: / www.x-rates.com/graph/?from $=$ USD\&to $=$ CAD\& amount $=1$ (accessed 1 June 2018). 